\title{
The Holly Bough service at Liverpool Cathedral and psychological type theory: Fresh expressions or inherited church?
}

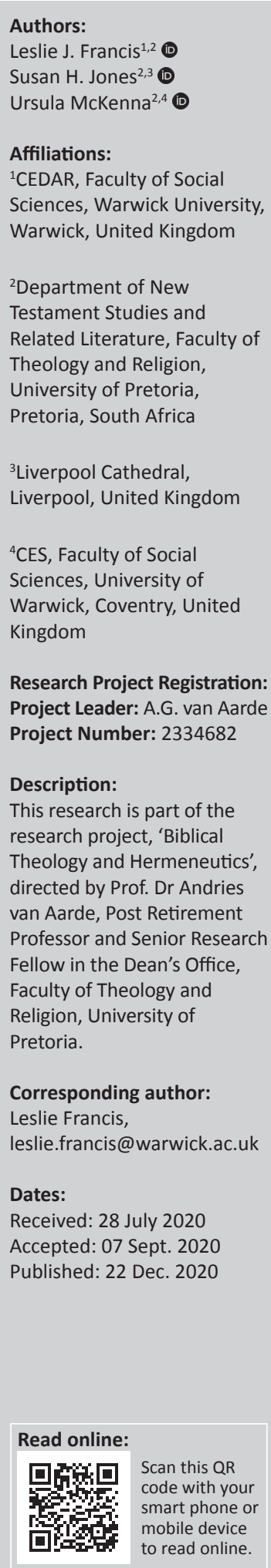

One of the key intentions of fresh expressions of church is to reach the kind of people inherited church find it hard to reach. Psychological type profiling of church congregations has demonstrated that Anglican churches have particular difficulty in reaching those whose Jungian judging preference is for thinking rather than for feeling. Studies that have explored the psychological type profile of participants within fresh expressions suggest that they do not significantly differ from inherited congregations in terms of reaching thinking types. Two previous studies, however, have reported higher proportions of thinking types attending cathedral carol services. The present study among 441 individuals attending the Holly Bough service in Liverpool Cathedral also found a higher proportion of thinking types among the participants. These findings suggest that cathedral carol services may be functioning as fresh expressions of church in a significant way.

Contribution: Situated within the science of cathedral studies, rooted in psychological type theory, and drawing on data from 441 attendees at the Holly Bough service, this study demonstrates that cathedral services at Christmas are more successful than either inherited church or fresh expressions of church in reaching thinking types.

Keywords: congregation studies; cathedral studies; psychological type; fresh expressions.

\section{Introduction}

\section{Introducing fresh expressions}

'Fresh expressions of Church' is a term coined by the Church of England (2004) in the report Mission-shaped Church: Church planting and fresh expressions of church in a changing context. The report took seriously recent research on church-leaving (Richter \& Francis 1998) and urged the Church to be creative in exploring a variety of ways through which to engage with people in changing social contexts. Chapter four of the report provided snapshots of 12 different kinds of fresh expressions of church which it characterised as: Alternative worship communities, Base Ecclesial Communities, Café church, Cell church, Churches arising out of community initiatives (both out of community projects and the restructuring or re-founding of an existing church to serve a community), Multiple and midweek congregations, Network-focused churches, School-based and school-linked congregations and churches, Seeker church, Traditional church plants, Traditional forms of church inspiring new interest, and Youth congregations. Each fresh expression, in its own way, seems motivated to reach people less well accessed by inherited church.

During the decade, following the publication of Mission-shaped Church, the fresh expressions movement was given further impetus by a series of studies, including Mission-shaped spirituality (Hope 2006), Mission-shaped and Rural (Gaze 2006), Mission-shaped children (Withers 2006), Missionshaped parish (Bayes \& Sledge 2006), Mission-shaped youth (Sudworth, Cray \& Russell 2007), Godshaped mission (Smith 2008), Mission-shaped questions (Croft 2008), Ancient faith, future mission: Fresh expressions in sacramental traditions (Croft \& Mobsby 2009), Church for every context (Moynagh 2012), Fresh expressions of church and the kingdom of God (eds. Cray, Kennedy \& Mobsby 2012) and Fresh!: An introduction to fresh expressions of church and pioneer ministry (Goodhew, Roberts \& Volland 2012). The fresh expressions movement has also attracted appropriate critique and

How to cite this article: Francis, L.J., Jones, S.H. \& McKenna, U., 2020, 'The Holly Bough service at Liverpool Cathedral and psychological type theory: Fresh expressions or inherited church?', HTS Teologiese Studies/Theological Studies 76(3), a6275. https://doi.org/10.4102/ hts.v76i3.6275

Copyright: ( 2020. The Authors. Licensee: AOSIS. This work is licensed under the Creative Commons Attribution License. 
commentary, as evidenced by Hull (2006), Milbank (2008), Nelstrop and Percy (2008), Percy (2010), Walker (2014), and Dunlop (2018).

The Church of England's (2014) Church Growth Research Project offered a good opportunity for the effectiveness of the fresh expression's initiatives to be assessed. Working within the context of this initiative, the Church Army's Research Unit (2013) examined over 1000 cases of fresh expressions supplied from ten dioceses (Blackburn, Bristol, Canterbury, Chelmsford, Derby, Leicester, Liverpool, Norwich, Portsmouth, and Ripon and Leeds). Employing ten clearly defined parameters of what counts as fresh expressions, 518 of these cases qualified for further examination as legitimate examples. Employing data that came from interviewing the leaders of these fresh expressions, the evidence suggested that these examples made up $15 \%$ of a diocese's church communities and $10 \%$ of overall attendance; the average size is usually smaller than average parish church congregations. For seven of the ten dioceses, the numbers of people participating in those fresh expressions equated to reversing the decline in average weekly attendance in these dioceses between 2006 and 2011, and in two other dioceses nearly did so. As part of this project, the leaders were invited to estimate the proportion of participants in fresh expressions representing three different categories, styled as Christians (25\%), de-churched $(35 \%)$ and non-churched (40\%).

Recognising some of the vulnerability in generalising on the basis of this study conducted among 10 dioceses, within the Church Army's Research Unit, Lings (2016) proposed a replication and extension study across 21 dioceses. This study also drew on leaders' estimation of the background of participants in fresh expressions. Compared with the findings from the initial study, this replication now reported 33\% as non-churched (compared with the original estimation of $40 \%$ ), 27\% as de-churched (compared with the original estimation of $35 \%$ ), and $40 \%$ as Christian (compared with the original estimation of $25 \%$ ).

In a third study within the Church Army's Research Unit, Dalpra and Vivian (2016) recognised that a richer and more accurate account of the background and trajectory of participants within fresh expressions would be obtained from surveying these individuals themselves rather than relying on the impression of the leaders. Using two questionnaires, one for young participants between the ages of five and ten and the other for all participants over the age of ten, Dalpra and Vivian (2016), obtained useable responses from 1997 individuals attending 66 fresh expressions across six dioceses. They discovered that the categorisation of participants into the three groups of churched, de-churched, and non-churched was too simplistic, and replaced this model with six categories, defined as:

- Churched: those who have been churchgoing Christians in all stages of their lives;
- Grown up in fresh expressions: those who have been part of fresh expressions since before the age of five;

- Simple de-churched: those who had been churchgoers but who had left for a period of more than two years before attending fresh expressions;

- Complex de-churched: those with longer de-churched backgrounds but who had reconnected with church, before attending fresh expressions;

- Simple non-churched: those who were not churchgoers, before attending fresh expressions;

- Complex non-churched: those who were not churchgoers but who had connected with church before attending fresh expressions.

Within these six categories, Dalpra and Vivian (2016) described $18 \%$ as simple non-churched, $6 \%$ as complex non-churched, $20 \%$ as simple de-churched, $19 \%$ as complex de-churched, $29 \%$ as churched, and $8 \%$ as grown up in fresh expressions.

Dalpra and Vivan (2016) also compared these 1997 participants in fresh expressions drawn from six dioceses with 953 attenders at inherited Sunday congregations across three dioceses. While $34 \%$ of the participants in these inherited congregations were male, the proportion rose to $39 \%$ of the participants in fresh expressions.

\section{Reaching the de-churched and the un-churched}

Underpinning the fresh expressions initiative was the realisation that the community of people closely involved in church life (as made visible by church attendance) was considerably overshadowed by two other communities characterised as the de-churched and un-churched. The de-churched community has been clearly exposed in England and Wales by the Church Leaving Applied Research Project as reported in the two volumes Gone but not forgotten (Richter \& Francis 1998) and Gone for good? (Francis \& Richter 2007). The de-churched are the people who used to attend but now, have given up attendance for a variety of reasons. The un-churched community has been clearly exposed in England and Wales by careful analyses of survey data undertaken in a series of studies by Voas (Voas \& Bruce 2019; Voas \& Watt 2014). The un-churched are people who have grown up as the second and third generation who have had no effective contact with church.

This elegant, if somewhat simplistic, threefold categorisation (churchgoers, de-churched and unchurched) has been further qualified and expanded by the insights of the two research traditions pioneered by Aisthorpe (2016) and by Walker (2017). Aisthorpe (2016) in his book The invisible church, draws attention to the experience of what he calls 'churchless Christians'. These are the people, for whom the Christian faith remains vital but for whom churches have become irrelevant. Walker (2017) in his book God's belongers: How people engage with God today draws attention to the multiple ways through which individuals may express their identity as Anglican. Some may belong through activities (attending 
services week by week), some may belong through events (attending, say, carol services once a year), some may belong through connections with people (vicarious belonging, through trusted individuals known to be linked with the local church), some may belong through place (being firmly linked with a church building or with the sacred plot in which family have been interred).

Against this background, the core question confronting research into the effectiveness of fresh expressions concerns identifying the extent to which these initiatives are being successful in reaching groups of people less well accessed by expressions of inherited church. This general thesis may be tested within a range of sociologically-informed conceptual frameworks concerned with categories like sex, age, ethnicity, social class, income level, or educational level. For example, a conceptual framework concerned with sex differences in participation rates might record the generally observed phenomenon that inherited church congregations comprise more women and men (Francis 1997; Francis \& Penny 2014) and propose that fresh expressions may attract a higher proportion of men to redress this sex imbalance. A conceptual framework concerned with age differences in participation rates might record the generally observed phenomena that inherited church congregations are heavily weighted toward the older generations (Francis 1996; Francis \& Lankshear in press) and propose that fresh expressions may attract a higher proportion of young people to redress this age imbalance. Characteristics like sex and age tend to be highly visible and, therefore, accessible to observation.

A somewhat different, but potentially useful conceptual framework, rooted not in sociological theory but in psychological theory, and now quite well-established in congregational studies, is that of psychological type theory. Psychological type theory has been applied in congregational studies by empirical research: conducted in North America by Bramer and Ross (2012), Delis-Bulhoes (1990), Gerhardt (1983), Rehak (1998) and Ross $(1993,1995)$; conducted in the United Kingdom by Craig et al. (2003), Francis (2013), Francis et al. (2004, 2007b), Francis, Robbins and Craig (2011), Francis and Robbins (2012), Lewis, Varvatsoulias and Williams (2012) and Village, Barker and Howat (2012) and conducted in Australia by Robbins and Francis (2011, 2012), Robbins, Francis and Powell (2012).

\section{Introducing psychological type theory}

Psychological type theory has its roots in the pioneering work of Carl Jung (1971) and has been developed and popularised through a series of type indicators, type sorters or type scales. The most frequently employed of these measures in church-related research and congregational studies are the Keirsey Temperament Sorter (KTS: Keirsey \& Bates 1978), the Myers-Brigg Type Indicator (MBTI: Myers \& McCaulley 1985) and the Francis Psychological Type Scales (FPTS: Francis 2005; Francis, Laycock \& Brewster 2017). At its core, psychological type theory distinguishes between two orientations, two perceiving functions, two judging functions, and two attitudes toward the outer world. In each of these four areas, psychological type theory conceptualises difference in terms of two discrete categories (or types) rather than in terms of a continuum stretching between two poles.

In psychological type theory, the two orientations are concerned with contrasting energy sources and distinguish between introversion (I) and extraversion (E). Introverts are energised by the inner world. When tired, they prefer to go inwards to regain energy. Extraverts are energised by the outer world. When tired, they prefer to congregate with other people to regain energy. Introverts enjoy their own company and appreciate silence. Extraverts enjoy the company of others and prefer to engage in conversation. A congregation shaped by introverts may seem somewhat strange to extraverts, while a congregation shaped by extraverts may seem somewhat strange to introverts.

In psychological type theory, the two perceiving functions are concerned with contrasting ways of taking in information and distinguish between sensing (S) and intuition (N). Sensing types are concerned with the details of a situation as perceived by the five senses. Intuitive types are concerned with the meaning and significance of a situation. Sensing types feel comfortable with the familiar, and with the conventional. They tend to dislike change. Intuitive types feel comfortable with innovation and with new ideas. They tend to promote change. A congregation shaped by sensing types may seem somewhat strange to intuitive types, while a congregation shaped by intuitive types may seem somewhat strange to sensing types.

In psychological type theory, the two judging functions are concerned with contrasting ways of evaluating situations and distinguish between thinking (T) and feeling (F). Thinking types are concerned with the objective evaluation of a situation, and with identifying the underlying logic. Feeling types are more concerned with the subjective evaluation of a situation, and with identifying the underlying values. Thinking types are more concerned with supporting effective systems. Feeling types are more concerned with supporting interpersonal relationships. A congregation shaped by thinking types may seem somewhat strange to feeling types, while a congregation shaped by feeling types may seem somewhat strange to thinking types.

In psychological type theory, the two attitudes toward the outer world are concerned with which of the two psychological processes is employed in the outer world and distinguish between judging $(\mathrm{J})$ and perceiving $(\mathrm{P})$. Judging types employ their preferred judging function (thinking or feeling) in the outer world. Perceiving types employ their preferred perceiving function (sensing or intuition) in the outer world. Judging types display a planned, orderly and organised profile to the outer world. Perceiving types display a flexible, spontaneous and unplanned profile to the outer world. A congregation shaped by judging types may seem somewhat strange to perceiving types, while a congregation 
shaped by perceiving types may seem somewhat strange to judging types.

As well as discussing the four contrasting pairs independently (introversion or extraversion, sensing or intuition, thinking or feeling, and judging or perceiving), psychological type theory draws these component parts together in a variety of ways, three of which are particularly important. First, the combination of the components allows each individual's strongest, or dominant function to be identified: dominant sensing types are practical people; dominant intuitive types are imaginative people; dominant feeling types are humane people; and dominant thinking types are logical people. Second, alongside their dominant preference individuals are given clearer identity by their second strongest, or auxiliary function. The auxiliary is the preferred function from the opposite process complementing the dominant function, leading to eight dominant-auxiliary pairs: dominant sensing with thinking, dominant sensing with feeling, dominant intuition with thinking, dominant intuition with feeling, dominant feeling with sensing, dominant feeling with intuition, dominant thinking with sensing, and dominant thinking with intuition. Third, all four preferred components of psychological type theory cohere to generate 16 complete types, usually identified by their initial letter (for example INTJ or ESFP).

\section{Establishing the psychological type profile of Anglican congregations}

In an initial pilot study, Francis et al. (2007b) analysed data from a sample of 185 churchgoers attending small congregations in rural Wales and compared the profile of male and female churchgoers with population norms for the United Kingdom published by Kendall (1998). The main finding from this comparison concerned the undue weighting toward sensing, feeling and judging in church congregations. Among women ISFJ accounts for 32\% of churchgoers, compared with $18 \%$ of the general population, and ESFJ accounts for $28 \%$ of churchgoers, compared with $19 \%$ of the general population. Among men ISFJ accounts for $19 \%$ of churchgoers, compared with $7 \%$ of the general population, and ESFJ accounts for $27 \%$ of churchgoers, compared with $6 \%$ of the general population. This somewhat stark finding raised the serious question regarding the source for such discrepancy. If God's call is equal to all psychological types, why are some types more likely to respond? Or is it conceivable that those who are responsible for relaying God's call through inherited church may be shaping that call in ways that resonate more strongly with certain types of people.

It would, however, have been seriously unwise to place too much weight on the findings from a study involving only 185 participants identified within small rural congregations in Wales. In a much more substantial replication of this initial study, Francis et al. (2011) drew together data from 2133 women and 1169 men surveyed in the context of Anglican church services in England and compared the psychological type profiles of these churchgoers with the population norms for the UK published by Kendall (1998). The findings from this larger study are remarkably similar to the findings from the smaller study (especially among the women). Among the female churchgoers there were strong preferences for sensing $(81 \%)$, for feeling $(70 \%)$, and for judging $(85 \%)$, with a balance between introversion (49\%) and extraversion (51\%). In this study $25 \%$ of the women reported ISFJ and $25 \%$ reported ESFJ. Among the male churchgoers there were preferences for introversion (62\%), for sensing (78\%), for thinking (58\%) and for judging (86\%). In this study $17 \%$ of the men reported ISFJ and $11 \%$ reported ESFJ.

Reviewing the findings from these two studies, Francis and Robbins (2012) advanced the hypothesis that, if introverts, sensing types, feeling types, and judging types (ISFJs) constitute the majority of Anglican churchgoers, extraverts, intuitive types, thinking types, and perceiving types (ENTPs) are the least likely to feel at home in the churches they attend. Francis and Robbins (2012) tested this hypothesis among a sample of 1867 churchgoers who completed a measure of psychological type, together with a measure of frequency of attendance and an index of congregational satisfaction. These data confirmed that congregations were weighted towards preferences for introversion, sensing, feeling, and judging (ISFJ), and the individuals displaying the opposite preferences (extraversion, intuition, thinking, and perceiving) recorded lower levels of congregational satisfaction. On the basis of these findings, Francis and Robbins (2012) took the view that not only were extraverts, intuitive types, thinking types, and perceiving types less in evidence in church congregations, those who were there were expressing lower levels of congregational satisfaction, and thus more likely to join the growing community of church leavers (see Francis \& Richter 2007).

\section{Establishing the psychological type profile of fresh expressions}

In an initial study designed to explore whether fresh expressions of church were reaching those psychological types inherited church find hard to reach, Francis, Clymo, and Robbins (2014) drew together data from 74 women and 49 men attending fresh expressions and compared the profiles of these participants with the profiles generated by Francis et al. (2011) of the 2135 women and the 1169 men attending inherited congregations. These data provided some support for the view that fresh expressions were reaching psychological types inherited church find it hard to reach, leading to the following four conclusions.

First, fresh expressions were attracting a higher proportion of intuitive types than inherited church. This finding was true among both women and men. Intuitive types are the people who like to try new things, who like to experiment and who are not tied to the traditional and to the conventional. It seems that fresh expressions may be well placed to engage the interest and support of intuitive types. 
Second, fresh expressions were attracting a higher proportion of extraverts than inherited church. This was true for women, but not for men. Extraverts are the people who are energised by social engagement and by activities. It seems that fresh expressions may be well placed to encourage participation, activities, and social engagement, at least in a way that appeals to extravert women. The kind of participation, activities, and social engagement seem, however, to be less attractive to extravert men.

Third, fresh expressions were attracting a higher proportion of perceiving types than inherited church. This was true for men, but not for women. Perceiving types are people who dislike being tied down to routine and who prefer a flexible environment that allows for spontaneity, for creativity, and for fun. It seems that fresh expressions may be well placed to create a flexible form of church, at least in a way that appeals to perceiving type men. The kind of flexibility offered, seems however, to be less attractive to perceiving type women.

Fourth, among neither men nor women were fresh expressions attracting a higher proportion of thinking types than inherited church.

In a second study, Village (2015) drew on data generated by the 2013 Church Times survey, to compare the psychological type profiles within the same survey of those who reported attending fresh expressions and those who reported not attending fresh expressions. The results for this study were quite close to the findings reported by Francis et al. (2014). Village (2015) reported that both men and women who attended fresh expressions showed stronger preferences for intuition and for extraversion; and that women who attended fresh expressions showed a stronger preference for perceiving. Neither men nor women who attended fresh expressions showed a stronger preference for thinking.

In a third study Francis, Wright and Robbins (2016) undertook a case study of one church that hosted three Sunday congregations, two in the form of inherited church and one in the form of a fresh expression. While no significant differences were found between the two inherited church congregations $(N=43$ and 110) and the profiles reported by Francis et al. (2011), the fresh expressions congregation $(N=43)$ was found to contain a significantly higher proportion of intuitive types. Once again, however, the fresh expressions congregation was failing to attract a higher proportion of thinking types.

In a fourth study, Aspland (2019) compared the psychological type profiles of 34 male and 154 female participants across 41 Messy Churches as a distinctive fresh expression (see Moore 2006; Paul 2017). These data found no significant differences across any of the four constructs proposed by psychological type theory.

The consistent negative conclusion across all four studies exploring the psychological type profile of participants engaged with fresh expressions of church is that these fresh expressions have so far failed to engage with more thinking types than is the case for inherited church. The difference between the thinking preference and the feeling preference is a profound difference and one that it may be particularly difficult for the inherited church (that is giving rise to fresh expressions) to grasp. There are two aspects to this profound difference. The first aspect concerns the ways in which thinking types and feeling types engage with the domain of religion. Thinking types engage first with their heads and are concerned with examining the logical coherence of religious teaching and religious beliefs. Feeling types engage first with their hearts and are concerned with experiencing and with participating in the community of interpersonal relationships and values that characterise the religious community. Fresh expressions may be better at modelling the relational approach to faith than modelling the critical approach. The second aspect concerns the clear connection between the thinking preference and masculinity and between the feeling preference and femininity. According to Kendall (1998) in the UK population $70 \%$ of women prefer feeling, while $65 \%$ of men prefer thinking. Inherited church has become captured, not only by women (who generally comprise between $60 \%$ and $70 \%$ of the congregation), but also by the feeling preference. Even the men who attend inherited church are more likely to prefer feeling than men in the general population. Moreover, the male leaders of inherited churches are much more likely to prefer feeling even than men in the congregations (see Francis et al. 2007a). It seems that fresh expressions may not as yet have broken the stereotype of church as a place mainly for women and mainly for feeling types.

\section{O come all ye thinking types}

It is against this background of the apparent failure of fresh expression to engage with thinking types that the findings of Walker's (2012) study among 164 men and 239 women, who attended the Christmas Carol Service in Worcester Cathedral in 2009, may be so intriguing. In light of his findings, Walker gave the following title to his papers, ' $\mathrm{O}$ come all ye thinking types: The wider appeal of the cathedral carol service'. Walker's data found that $69 \%$ of the men attending his cathedral carol services preferred thinking, compared with 58\% in ordinary Anglican congregations (Francis et al. 2011) and 65\% in the UK population (Kendall 1998). Walker's data found that $39 \%$ of the women attending his cathedral carol services preferred thinking, compared with $30 \%$ in ordinary Anglican congregations (Francis et al. 2011) and 30\% in the UK population (Kendall 1998). Walker also found a higher proportion of intuitive types attending his cathedral carol services: $27 \%$ of the women attending his carol services, compared with $19 \%$ in ordinary Anglican congregations and $21 \%$ in the UK population, and $30 \%$ of the men attending his carol services, compared with $22 \%$ in ordinary Anglican congregations and $27 \%$ in the UK population. 
Speculating about why cathedral carol services may attract a higher proportion of intuitive types compared with ordinary Anglican congregations, Walker argued that there are two distinctive qualities that characterise the cathedral carol service. First, the carol service offers a performance with very high production values, involving a professional choir, a skilled organist, and a wide range of music, all within an evocatively lit ancient building. There is much to engage the senses, but also to spark the imagination. Second, Walker argued that the lessons and carols relate the Christian story in a way that goes beyond the senses and hints at a 'deeper mystery understood or apprehended in the depths of the human soul; a process that fits well with an intuitive style' (p. 993).

Speculating about why cathedral carol services may attract a higher proportion of thinking types compared with ordinary Anglican congregations, Walker argued that there may be an objectivity about the structure of carol services that set them apart from the usual pattern of Anglican church services. Drawing on data about the tendency for Anglican clergymen to display a much higher preference for feeling than men in the general population (Francis, et al. 2007a), Walker suggested:

[T] he likelihood that Anglican church services are largely planned and led by feeling types who will have a predisposition to assume that the idiom that works for them is one that will work for everybody. (p. 994)

In the spirit of scientific replication studies, Francis, Edwards, and ap Siôn (2020) reapplied Walker's survey among 193 participants attending carol services at Bangor Cathedral in 2013, 56 men and 137 women. In light of the smaller numbers they did not analyse the data for men and women separately but compared the combined profile with the combined profile for men and women calculated from the survey of Anglican churchgoers reported by Francis et al. (2011). The data from Bangor Cathedral also reported a significantly higher proportion of intuitive types attending the carol service $(27 \%$ compared with $20 \%$ in ordinary Anglican congregations) and a significantly higher proportion of thinking types attending the carol service (52\% compared with $40 \%$ in ordinary Anglican congregations).

\section{Research question}

Against the background of the studies reported by Francis et al. (2020) and by Walker (2012) the aim of the present study is to explore the psychological type profile of participants attending the highly distinctive Holly Bough Service at Liverpool Cathedral in 2019. The Holly Bough Service is an event unique to Liverpool Cathedral, combining musical excellence and theological depth, crafted especially for Liverpool Cathedral in the early twentieth century.

The Holly Bough service was designed by Frederick William Dwelly, the first Dean of Liverpool Cathedral, who is celebrated by his biographer Peter Kennerley (2015) as the 'liturgical genius'. In some senses this service stands in the tradition of the Festival of Nine Lessons and Carols that was inaugurated in King's College Chapel Cambridge on Christmas Eve 1918, but it differs from that long-established service in two important ways. First, it was designed not for Christmas Eve, but for the Fourth Sunday of Advent when the liturgical mood is quite different. Second, it was designed not only as a vehicle for a rich choral tradition and the proclamation of scripture (with five, rather than nine readings from scripture and one non-scriptural reading) but also as a vehicle for liturgical drama and powerful symbolism.

The central drama of the Holly Bough service follows the fifth reading. Then attention is turned to the west end of the cathedral where a life-size manger is already in place. From the west end an Advent candle stand entirely wrapped in holly and crowned with five lit candles is carried in solemn procession to the high altar, above which the reredos displays the crucifixion. The drama is enhanced by the way in which the lights are dimmed. In this way, the Holly Bough represents the Christ progressing from crib to cross, linking liturgically the glorious birth and the humiliating death of the one for whom the Season of Advent is still preparing. At the high altar the Dean blesses the Holly Bough, and the Bishop concludes the service with the final reading, collect and blessing.

\section{Method Procedure}

When people came into the cathedral for the Holly Bough service, the welcomers gave them a copy of the service and a white envelope containing the questionnaire and a pen. The welcomers invited participants to complete the first part of the questionnaire while they were waiting for the service to start. This invitation was reinforced by the video screens organised around the cathedral to relay the service. At the close of the service, 564 questionnaires were returned with full demographic data.

\section{Instrument}

Psychological type was assessed by the FPTS (Francis 2005; Francis et al. 2017). This is a 40-item instrument comprising four sets of 10 forced-choice items related to each of the four components of psychological type: orientation (extraversion or introversion), perceiving process (sensing or intuition), judging process (thinking or feeling), and attitude toward the outer world (judging or perceiving). Recent studies have demonstrated that this instrument functions well in churchrelated contexts. For example, Francis, Craig and Hall (2008) reported alpha coefficients of 0.83 for the EI scale, 0.76 for the SN scale, 0.73 for the TF scale and 0.79 for the JP scale. Participants were asked for each pair of characteristics to:

'Check the 'box next to that characteristic which is closer to the real you, even if you feel both characteristics apply to you. Tick the characteristics that reflect the real you, even if other people see you differently'. 


\section{Participants}

Of the 564 participants who returned questionnaires with full demographic data, 441 had thoroughly completed the Francis Psychological Type Scales. Of these 441 participants, 161 were male, 278 were female, and 2 did not identify; 15 were under the age of twenty; 41 in their twenties, 36 in their thirties; 57 in their forties; 101 in their fifties; 109 in their sixties, 67 in their seventies and 15 were aged eighty and over. The majority described their present or most recent work as professional or semi-professional (78\%). Just over half described themselves as attending church fewer than six times a year $(52 \%)$, compared with $22 \%$ who described themselves as attending church nearly every week.

\section{Analysis}

The research literature concerning the empirical investigation of psychological type has developed a highly distinctive method for analysing, handling, and displaying statistical data in the form of 'type tables'. This convention has been adopted in the following presentation in order to integrate these new data within the established literature and to provide all the detail necessary for secondary analysis and further interpretation within the rich theoretical framework afforded by psychological type. Type tables have been designed to provide information about the sixteen discrete psychological types, about the four dichotomous preferences, about the six sets of pairs and temperaments, about the dominant types, and about the introverted and extraverted Jungian types. Commentary on these tables will, however, be restricted to those aspects of the data strictly relevant to the research question. In the context of type tables, the statistical significance of the difference between two groups is established by means of the selection ratio index $(I)$, an extension of chi-square (McCaulley 1985).

\section{Results}

The aim of this study was to compare the psychological type profile of the congregation attending the Holly Bough service at Liverpool Cathedral with the normative profiles for Anglican congregations that could be retrieved from the participants in the study reported by Francis et al. (2011). The first step was to compute the normative profile from that study by aggregating the responses of men and women. Table 1, therefore, presents the aggregated type distribution for 3302 individuals (2133 women and 1169 men) drawn from 140 Church of England congregations. These data confirm preferences for introversion (54\%) over extraversion $(46 \%)$, for sensing $(80 \%)$ over intuition $(20 \%)$, for feeling $(60 \%)$ over thinking (40\%), and for judging (86\%) over perceiving (14\%). Within this group of 3302 Anglican churchgoers, the most frequently occurring of the sixteen complete types were ISFJ (22\%), ESFJ (20\%), ISTJ (18\%) and ESTJ (12\%).

The Francis Psychological Type Scales reported satisfactory internal consistency reliability among the participants at the
TABLE 1: Type distribution for Anglican congregations.

\begin{tabular}{|c|c|c|c|c|c|c|c|c|}
\hline \multicolumn{5}{|c|}{ The 16 complete types } & \multicolumn{4}{|c|}{ Dichotomous preferences } \\
\hline ISTJ & ISFJ & INFJ & \multicolumn{2}{|c|}{ INTJ } & $\mathrm{E}$ & \multicolumn{2}{|c|}{$n=1527$} & $(46.2 \%)$ \\
\hline$n=598$ & $n=729$ & $n=108$ & \multicolumn{2}{|c|}{$n=128$} & I & \multicolumn{2}{|c|}{$n=1775$} & $(53.8 \%)$ \\
\hline$(18.1 \%)$ & $(22.1 \%)$ & $(3.3 \%)$ & \multicolumn{2}{|c|}{$(3.9 \%)$} & - & \multicolumn{2}{|c|}{-} & - \\
\hline +++++ & +++++ & +++ & \multicolumn{2}{|c|}{++++} & S & \multicolumn{2}{|c|}{$n=2641$} & $(80.0 \%)$ \\
\hline+++++ & +++++ & - & \multicolumn{2}{|c|}{-} & $\mathrm{N}$ & \multicolumn{2}{|c|}{$n=661$} & $(20.0 \%)$ \\
\hline+++++ & +++++ & - & \multicolumn{2}{|l|}{-} & - & \multicolumn{2}{|c|}{-} & - \\
\hline \multirow[t]{2}{*}{+++} & +++++ & - & \multicolumn{2}{|l|}{-} & $\mathrm{T}$ & \multicolumn{2}{|c|}{$n=1319$} & $(39.9 \%)$ \\
\hline & ++ & - & \multicolumn{2}{|l|}{-} & $\mathrm{F}$ & \multicolumn{2}{|c|}{$n=1983$} & $(60.1 \%)$ \\
\hline- & - & - & \multicolumn{2}{|l|}{-} & - & & & - \\
\hline- & - & - & - & & J & $n=2$ & & $(85.7 \%)$ \\
\hline- & - & - & - & & $\mathrm{P}$ & $n=4$ & & $(14.3 \%)$ \\
\hline ISTP & ISFP & INFP & & NTP & - & & & - \\
\hline$n=36$ & $n=88$ & $n=61$ & & $l=27$ & Pairs & temp & ament & \\
\hline$(1.1 \%)$ & $(2.7 \%)$ & $(1.8 \%)$ & & $0.8 \%)$ & IJ & $n=1$ & & $(47.3 \%)$ \\
\hline+ & +++ & ++ & + & & IP & $n=2$ & & $(6.4 \%)$ \\
\hline- & - & - & - & & EP & $n=2$ & & $(7.9 \%)$ \\
\hline- & - & - & - & & EJ & $n=1$ & & $(38.4 \%)$ \\
\hline - & - & - & - & & - & & & - \\
\hline - & - & - & - & & ST & $n=1$ & & $(31.7 \%)$ \\
\hline- & - & - & - & & SF & $n=1$ & & $(48.3 \%)$ \\
\hline - & - & - & - & & $\mathrm{NF}$ & $n=3$ & & $(11.8 \%)$ \\
\hline ESTP & ESFP & ENFP & & NTP & NT & $n=2$ & & $(8.3 \%)$ \\
\hline$n=22$ & $n=116$ & $n=89$ & & $t=33$ & - & 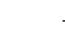 & & - \\
\hline$(0.7 \%)$ & $(3.5 \%)$ & $(2.7 \%)$ & & $1.0 \%)$ & SJ & $n=2$ & & $(72.0 \%)$ \\
\hline+ & ++++ & +++ & + & & SP & $n=2$ & & $(7.9 \%)$ \\
\hline - & - & - & - & & $\mathrm{NP}$ & $n=2$ & & $(6.4 \%)$ \\
\hline - & - & - & - & & NJ & $n=4$ & & $(13.7 \%)$ \\
\hline - & - & - & - & & - & 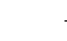 & & - \\
\hline - & - & - & - & & TJ & $n=1$ & & $(36.4 \%)$ \\
\hline- & - & - & - & & TP & $n=1$ & & $(3.6 \%)$ \\
\hline - & - & - & - & & FP & $n=3$ & & $(10.7 \%)$ \\
\hline- & - & - & - & & FJ & $n=1$ & & $(49.3 \%)$ \\
\hline ESTJ & ESFJ & ENFJ & & NTJ & - & . & & - \\
\hline$n=390$ & $n=662$ & $n=130$ & & $y=85$ & IN & $n=3$ & & $(9.8 \%)$ \\
\hline$(11.8 \%)$ & $(20.0 \%)$ & $(3.9 \%)$ & & $2.6 \%)$ & EN & $n=3$ & & $(10.2 \%)$ \\
\hline +++++ & +++++ & ++++ & & -++ & IS & $n=1$ & & $(43.9 \%)$ \\
\hline+++++ & +++++ & - & - & & ES & $n=1$ & & $(36.0 \%)$ \\
\hline++ & +++++ & - & - & & - & & & - \\
\hline- & +++++ & - & - & & ET & $n=5$ & & (16.1\%) \\
\hline - & - & - & - & & $\mathrm{EF}$ & $n=9$ & & $(30.2 \%)$ \\
\hline- & - & - & - & & IF & $n=9$ & & $(29.9 \%)$ \\
\hline- & - & - & - & & IT & $n=7$ & & $(23.9 \%)$ \\
\hline Jung & an types ( & & & ungian typ & & & inant $t$ & ypes \\
\hline & $n$ & $\%$ & & $n$ & $\%$ & & $n$ & $\%$ \\
\hline E-TJ & 475 & 14.4 & I-TP & 63 & 1.9 & Dt.T & 538 & 16.3 \\
\hline E-FJ & 792 & 24.0 & I-FP & 149 & 4.5 & Dt.F & 941 & 28.5 \\
\hline ES-P & 138 & 4.2 & IS-J & 1327 & 40.2 & Dt.S & 1465 & 44.4 \\
\hline EN-P & 122 & 307 & IN-J & 236 & 7.1 & Dt.N & 358 & 10.8 \\
\hline
\end{tabular}

Note: $N=3302$ (NB: $+=1 \%$ of $N$ ).

Holly Bough service in Liverpool Cathedral with the following alpha coefficients (Cronbach, 1951): introversion and extraversion, $\alpha=0.75$; sensing and intuition, $\alpha=0.66$; feeling and thinking, $\alpha=0.67$; judging and perceiving, $\alpha=0.73$. Table 2 employs the data generated by these scales to map the psychological type profile of those attending the Holly Bough service. These data demonstrate preferences for introversion (55\%) over extraversion (45\%), for sensing (77\%) over intuition $(23 \%)$, for feeling $(53 \%)$ over thinking $(47 \%)$, and for judging (85\%) over perceiving (15\%). Within this group of 441 participants the most frequently occurring of 
TABLE 2: Type distribution for participants at the Holly Bough service compared to Anglican congregations.

\begin{tabular}{|c|c|c|c|c|c|c|c|c|c|c|}
\hline \multicolumn{6}{|c|}{ The 16 complete types } & \multicolumn{5}{|c|}{ Dichotomous preferences } \\
\hline ISTJ & \multicolumn{2}{|c|}{ ISFJ } & INFJ & \multicolumn{2}{|c|}{ INTJ } & $E$ & $n=197$ & $(44.7 \%)$ & \multicolumn{2}{|c|}{$I=0.97$} \\
\hline$n=99$ & \multicolumn{2}{|c|}{$n=80$} & $n=15$ & \multicolumn{2}{|c|}{$n=20$} & 1 & $n=244$ & $(55.3 \%)$ & \multicolumn{2}{|c|}{$I=1.03$} \\
\hline$(22.4 \%)$ & \multicolumn{2}{|c|}{$(18.1 \%)$} & $(3.4 \%)$ & \multicolumn{2}{|c|}{$(4.5 \%)$} & - & - & - & \multicolumn{2}{|l|}{-} \\
\hline$I=1.24 *$ & \multicolumn{2}{|c|}{$I=0.82$} & $I=1.04$ & \multicolumn{2}{|c|}{$I=1.17$} & S & $n=338$ & $(76.6 \%)$ & \multicolumn{2}{|c|}{$I=0.96$} \\
\hline+++++ & \multicolumn{2}{|c|}{ +++++ } & +++ & \multicolumn{2}{|c|}{+++++} & $\mathrm{N}$ & $n=103$ & $(23.4 \%)$ & \multicolumn{2}{|c|}{$I=1.17$} \\
\hline+++++ & \multicolumn{2}{|c|}{+++++} & - & - & & - & - & - & \multicolumn{2}{|l|}{-} \\
\hline++++ & +++ & & - & - & & $\mathrm{T}$ & $n=209$ & $(47.4 \%)$ & $I=1$ & $.19 * *$ \\
\hline++++ & +++ & & - & - & & $\mathrm{F}$ & $n=232$ & $(52.6 \%)$ & $I=0$ & $.88 * *$ \\
\hline++ & & & - & - & & - & - & - & - & \\
\hline- & - & & - & - & & J & $n=373$ & $(84.6 \%)$ & $I=0$ & .99 \\
\hline- & - & & - & - & & $P$ & $n=68$ & $(15.4 \%)$ & $I=1$ & .08 \\
\hline ISTP & ISFP & & INFP & INT & JTP & - & - & - & - & \\
\hline$n=9$ & $n=$ & & $n=12$ & & $=6$ & Pai & s and temp & eraments & & \\
\hline$(2.0 \%)$ & $(0.7$ & & $(2.7 \%)$ & & $.4 \%)$ & IJ & $n=214$ & $(48.5 \%)$ & $I=1$ & .03 \\
\hline$I=1.37$ & $I=C$ & $26 * *$ & $I=1.47$ & & $=1.66$ & IP & $n=30$ & $(6.8 \%)$ & $I=1$ & .06 \\
\hline++ & + & & +++ & + & & EP & $n=38$ & $(8.6 \%)$ & $I=1$ & .09 \\
\hline- & - & & - & - & & EJ & $n=159$ & $(36.1 \%)$ & $I=0$ & .94 \\
\hline- & - & & - & - & & - & - & - & - & \\
\hline- & - & & - & - & & ST & $n=167$ & $(37.9 \%)$ & $I=1$ & $.20 * *$ \\
\hline - & - & & - & - & & SF & $n=171$ & $(38.8 \%)$ & $I=0$ & $.80 * * *$ \\
\hline- & - & & - & - & & $\mathrm{NF}$ & $n=61$ & $(13.8 \%)$ & $I=1$ & .18 \\
\hline ESTP & ESF & & ENFP & & VTP & NT & $n=42$ & $(9.5 \%)$ & $I=1$ & .15 \\
\hline$n=6$ & $n=$ & & $n=12$ & & $=7$ & - & - & - & - & \\
\hline$(1.4 \%)$ & $(2.9$ & & $(2.7 \%)$ & & $.6 \%)$ & SJ & $n=307$ & $(69.6 \%)$ & $I=0$ & .97 \\
\hline$I=2.04$ & $I=0$ & & $I=1.01$ & & $=1.59$ & SP & $n=31$ & $(7.0 \%)$ & $I=0$ & .89 \\
\hline+ & +++ & & +++ & ++ & & NP & $n=37$ & $(8.4 \%)$ & $I=1$ & 32 \\
\hline- & - & & - & - & & NJ & $n=66$ & $(15.0 \%)$ & $I=1$ & .10 \\
\hline- & - & & - & - & & - & - & - & - & \\
\hline- & - & & - & - & & TJ & $n=181$ & $(41.0 \%)$ & $I=1$ & .13 \\
\hline- & - & & - & - & & $\mathrm{TP}$ & $n=28$ & $(6.3 \%)$ & $I=1$ & $.78 * *$ \\
\hline- & - & & - & - & & FP & $n=40$ & $(9.1 \%)$ & $I=0$ & .85 \\
\hline- & - & & - & - & & FJ & $n=192$ & $(43.5 \%)$ & $I=0$ & $.88^{*}$ \\
\hline ESTJ & ESF & & ENFJ & EN & VTJ & - & - & - & - & \\
\hline$n=53$ & $n=$ & & $n=22$ & $n=$ & $=9$ & IN & $n=53$ & $(12.0 \%)$ & $I=1$ & .22 \\
\hline$(12.0 \%)$ & (17. & $\%)$ & $(5.0 \%)$ & & $.0 \%)$ & EN & $n=50$ & $(11.3 \%)$ & $I=1$ & .11 \\
\hline$I=1.02$ & $I=C$ & & $I=1.27$ & & $=0.79$ & IS & $n=191$ & $(43.3 \%)$ & $I=0$ & .99 \\
\hline +++++ & +++ & & +++++ & ++ & & ES & $n=147$ & $(33.3 \%)$ & $I=0$ & .92 \\
\hline+++++ & +++ & & - & - & & - & - & - & - & \\
\hline++ & +++ & & - & - & & ET & $n=75$ & $(17.0 \%)$ & $I=1$ & .06 \\
\hline- & ++ & & - & - & & $\mathrm{EF}$ & $n=122$ & $(27.7 \%)$ & $I=0$ & .92 \\
\hline- & - & & - & - & & IF & $n=110$ & $(24.9 \%)$ & $I=0$ & $.84^{*}$ \\
\hline- & - & & - & - & & IT & $n=134$ & $(30.4 \%)$ & $I=1$ & $.27 * *$ \\
\hline Jung & $\operatorname{gian} t$ & ppes (E & & & Jungian & types & & Dominar & nt typ & \\
\hline & $n$ & $\%$ & $\overline{\text { Index }}$ & & $n$ & $\%$ & Index & $n$ & $\%$ & Index \\
\hline E-TJ & 62 & 14.1 & 0.98 & I-TP & 15 & 3.4 & 1.78* Dt.T & 77 & 17.5 & 1.07 \\
\hline E-FJ & 97 & 22.0 & 0.92 & I-FP & 15 & 3.4 & 0.75 Dt.F & 112 & 25.4 & 0.89 \\
\hline ES-P & 19 & 4.3 & 1.03 & IS-J & 179 & 40.0 & 1.01 Dt.S & 198 & 44.9 & 1.01 \\
\hline EN-P & 19 & 4.3 & 1.17 & IN-J & 35 & 7.9 & 1.11 Dt.N & 54 & 12.2 & 1.13 \\
\hline
\end{tabular}

Note: $N=441$ (NB: $+=1 \%$ of $N$ )

$*, p<0.05 ; * *, p<0.01 ; * * *, p<0.001$

the sixteen complete types were ISTJ (22\%), ISFJ (18\%), and ESFJ (17\%).

Figure 2 also presents the statistical significance of differences presented in the profile of participants at the Holly Bough service and participants of the ordinary Anglican congregations profiled in Figure 1. In terms of the dichotomous preferences, no significant differences between the two samples were reported in terms of the two orientations (extraversion and introversion), the two perceiving functions (sensing and intuition) and the two attitudes (judging and perceiving). However a significant difference between the two samples was reported in terms of the two judging functions (thinking and feeling). While the proportion of thinking types in ordinary Anglican congregations stood at $40 \%$, at the Holly Bough service the proportion rose to $47 \%$.

\section{Discussion and conclusion}

The present study was rooted in two theoretical frameworks. The first framework was shaped by the formative report Mission-shaped Church: Church planting and fresh expressions of Church in a changing context (Church of England, 2004) that stimulated and challenged the Church of England to explore fresh expressions of church capable of reaching sections of the population that inherited church seemed less successful in reaching. The second theoretical framework was shaped by a branch of congregation studies that profiles congregations in psychological rather than sociological categories. While sociologists of religion may helpfully observe and measure variation in attendance according to sex (men compared with women), according to age (young adults compared with seniors), or according to social class (manual workers compared with professional careers), psychologists of religion may explore and measure variations in attendance according to psychological profiling. The model of psychological profiling that seems to be particularly powerful in terms of both the science of congregation studies (Francis et al. 2011) and the science of clergy studies (Ross \& Francis 2020), is the model of psychological type theory as proposed by Jung (1971), and developed by a range of psychometric instruments, including the Keirsey Temperament Sorter (Keirsey \& Bates 1978), the Myers-Briggs Type Indicator (Myers \& McCaulley 1985) and the Francis Psychological Type Scales (Francis 2005; Francis et al. 2017).

Drawing specifically on a branch of the science of congregation studies that has employed psychological type theory and measurement, the review of current literature formulated three tentative conclusions: first, that inherited church congregations are heavily weighted in favour of feeling types at the expense of thinking types (Francis et al. 2007b, 2011); second, that currently, there is no evidence to suggest that fresh expressions of church are more successful in reaching thinking types than inherited church (Aspland 2019; Francis et al. 2014, 2016; Village 2015) and third, that cathedral carol services were more successful in reaching thinking types than inherited church (Francis et al. 2020; Walker 2012). The present study added to this developing body of knowledge by demonstrating that the Holly Bough service in Liverpool Cathedral 2019 was also more successful in reaching thinking types than inherited church.

The real drawback in applying scientific methods to congregation studies concerns the slow and persistent way in which new knowledge is generated and rigorously tested. Replication studies are crucial in building up reliable 
knowledge of this kind. On the other hand, the real advantage in applying scientific methods to congregation studies concerns the way in which knowledge generated by this method may be secure enough on which to make firm recommendation regarding best practice and future investment. The claim that could be made on the basis of the current scientific evidence is that, in as yet unrecognised ways, cathedrals may represent the most robust fresh expressions available within the renewal strategies of the Church of England, with capacity to reach some psychological types not so readily accessed either by inherited church or by recognised fresh expressions of church.

This recommendation, nonetheless, remains vulnerable to three potentially serious criticisms. The first and most scientifically serious criticism, voiced on empirical grounds, is that the scientific evidence remains relatively slim. The number of studies is small and the sample size for some of these studies is also small. This is a problem that could be resolved by significant targeted investment. Current evidence, however, suggests that the Church of England is not yet convinced about the contribution that can be made by the psychology of religion to the church growth agenda. Neither the original investment within the Church Growth Research Programme, nor subsequent commissioned studies have directly embraced this perspective. Indeed, when the sociologist of religion, David Voas, included psychological measures in his study and reported that psychological factors provided the strongest predictors of church growth (Voas \& Watt 2014), that specific finding was omitted from the authoritative report From anecdote to evidence (Church of England 2014). The way in which some evidence is taken more seriously than others in the church growth agenda has been documented by Francis (2016).

The second and most strategically damaging criticism, voiced on theological grounds, is that the description of individual differences advanced by psychological theory, may be irrelevant within a theological environment in which faith is placed in the transforming power of the Holy Spirit. This objection has, however, been seriously addressed by the theological perspective known as the theology of individual differences. This perspective carefully balances the doctrinal system of creation, fall, redemption, and sanctification. The theology of individual differences is firmly rooted in a reading of Genesis 1: 22, and in a God who intentionally creates differences embraced within the divine image (Francis \& Village 2008, 2015). Further theological debate in this domain is worth investigation.

The third criticism, voiced on both theological and psychological grounds, concerns interrogation of the significance of the Jungian judging process that distinguishes between the functions of feeling and thinking. Why should the Anglican Church be concerned to embrace thinking types rather than pray that they may repent and be converted into feeling types? Why should God be concerned about thinking types anyway? And what may thinking types offer to the Church community? Such troubling questions need to be addressed by revisiting the judging process. Within Jungian theory, the judging process is characterised as the rational process, it is concerned with evaluating, weighing, and judging. Within Jungian theory the preference between thinking and feeling reflects an innate predisposition fundamental to an individual's identity. Within a theology of individual differences the preference between thinking and feeling reflects a fundamental difference intended by the divine creator, respected and loved.

So in what ways are feeling and thinking reflected in human behaviour? The preference for feeling is reflected in deep commitment to base evaluations and judgements on subjective values and interpersonal relational concerns. Peace and harmony are there at the centre. The God of Mercy is the God who matters most. The preference for thinking is reflected in deep commitment to base evaluations and judgements on objective standards and impersonal logic. Truth and justice are there at the centre. The God of Justice is the God who matters most. Surely, there must be a place for dialogue between feeling and thinking within the Christian community and acceptance of both functions, just as there is a theological dialogue between the attributes of the God of Mercy and the attributes of the God of Justice? This question regarding the place for thinking as well as the place for feeling within the Christian community is further illuminated by three other strands of research.

First, while the other three constructs proposed by psychological type theory (the orientations, the perceiving functions, and the attitudes) are not reflected in strong differences between men and women, the judging functions are reflected in strong differences between men and women. According to the UK population norms, 35\% of men prefer feeling compared with $70 \%$ of women (Kendall, 1998). What is really fascinating from the research data is that the men in the pews of Anglican inherited church are slightly more likely than men in general to prefer feeling (42\% instead of 35\% according to Francis et al. 2011), while the men ordained in the Anglican Church are much more likely than men in general to prefer feeling (54\% instead of 35\%, according to Francis et al. 2007a). By prioritising the feeling function, the Anglican Church may be making access for men unnecessarily difficult. By way of contrast, research among Newfrontiers Network of Churches finds a somewhat different outcome. In a study among 154 leaders in this context, Francis, Robbins, and Ryland (2012) found preference for feeling standing at $40 \%$.

Second, a stream of qualitative research has examined the implications of preferences for feeling and for thinking for pastoral practice among Anglican clergy. Smith (2015) and Smith and Francis (2015) report on three studies conducted among curates and training incumbents. On each occasion there were more feeling types than thinking types: 13 compared 
with 10 in study one, 17 compared with 10 in study two, and 10 compared with 5 in study three. All three studies illustrated the fundamental contrast in formulating and exercising pastoral practice between feeling types and thinking types. Best pastoral practice, however, may emerge when feeling and thinking types collaborate, share pastoral responsibilities, and both discuss and evaluate outcomes of different approaches.

Third, a second stream of qualitative research has illuminated, from the reader perspective approach to biblical hermeneutics, the distinctive voices of feeling types and thinking types in the pulpit, as summarised by Francis, Jones, and Hebden (2019). For example, in a paper entitled 'Psychologically informed engagement with the Matthean pericopes on Pilate and Judas through Jungian lenses', Francis and Ross (2018) draw on the workshop convened by Waterloo Lutheran Seminary, involving 9 thinking type and 15 feeling type experienced preachers, to illuminate contrasting readings of Matthew 27:3-10. A richer interpretation of scripture emerges when feeling types and thinking types collaborate and both discuss and evaluate their distinctive readings of sacred text.

Cumulatively, these three strands of research suggest that there may be real hermeneutical, pastoral and missional reasons for taking seriously opportunities for fresh expressions of church to reach out to thinking types in ways that effectively extend the reach of inherited church. Evidence suggests that cathedrals may be well placed to learn from the experience of their carol services in order to replicate the experience on other occasions. Indeed, Bishop David Walker (2012) concluded his analysis of the implications from the findings derived from the carol services in Worcester Cathedral by suggesting that cathedrals 'should be looking to construct other church services through the year that will match the type appeal of the carol service'. This is a challenge offered by a bishop to the cathedral community that is well worth proper consideration.

\section{Acknowledgements Competing interests}

The authors have declared that no competing interests exist.

\section{Authors' contributions}

Leslie Francis took responsibility for overall conceptualisation of the paper. Susan Jones oversaw the involvement of the cathedral in the project and assessed the literature relevant to fresh expressions and cathedral ministry. Ursula McKenna curated the data and gave oversight to the data analysis.

\section{Ethical consideration}

This article followed all ethical standards for a research without direct contact with human or animal subjects.

\section{Funding information}

This research received no specific grant from any funding agency in the public, commercial or not-for-profit sectors.

\section{Data availability statement}

Data are available from the first author.

\section{Disclaimer}

The views and opinions expressed in this article are those of the authors and do not necessarily reflect the official policy or position of any affiliated agency of the authors.

\section{References}

Aisthorpe, S., 2016, The invisible church: Learning from the experience of churchless Christians, St Andrew Press, Edinburgh.

Aspland, A.D., 2019, 'Ordering the mess: Psychological type profiles of adults in Messy Church congregations', Research in the Social Scientific Study of Religion 29(1), 1-21. https://doi.org/10.1163/9789004382640_002

Bayes, P. \& Sledge, T., 2006, Mission-shaped parish: Traditional church in a changing context, Church House Publishing, London.

Bramer, P.D.G. \& Ross, C.F.J., 2012, 'Type patterns among evangelical protestants in Ontario', Mental Health, Religion and Culture 15(10), 997-1007. https://doi.org/1 $0.1080 / 13674676.2012 .678577$

Church Army's Research Unit, 2013, Analysis of fresh expressions of Church and Church plants began in the period 1992-2012, Church Army, Sheffield.

Church of England, 2004, Mission-shaped church: Church planting and fresh expressions of church in a changing context, Church House Publishing, London.

Church of England, 2014, From anecdote to evidence: Findings from the Church growth research programme 2011-2013, Church Commissioners for England, London.

Craig, C.L., Francis, L.J., Bailey, J. \& Robbins, M., 2003, 'Psychological types in Church in Wales congregations', The Psychologist in Wales 15(1), 18-21.

Cray, G., Kennedy, A. \& Mobsby, I. (eds.), 2012, Fresh expressions of church and the kingdom of God, Canterbury Press, London.

Croft, S., 2008, Mission-shaped questions: Defining issues for today's church, Church House Publishing, London.

Croft, S. \& Mobsby, I., 2009, Ancient faith, future mission: Fresh expressions in sacramental traditions, Canterbury Press, Norwich.

Cronbach, L.J., 1951, 'Coefficient alpha and the internal structure of tests', Psychometrika 16(1), 297-334. https://doi.org/10.1007/BF02310555

Dalpra, C. \& Vivian, J., 2016, Who's there? The church backgrounds of Anglican fresh expressions of church attenders, Church Army, Sheffield.

Davison, A. \& Milbank, A., 2010, For the parish:1 A critique of fresh expressions, SCM Press, London.

Delis-Bulhoes, V., 1990, 'Jungian psychological types and Christian belief in active church members', Journal of Psychological Type 20(1), 25-33.

Dunlop, A., 2018, Out of nothing: A cross-shaped approach to fresh expressions, SCM Press, London.

Francis, L.J., 1996, Church watch: Christianity in the countryside, SPCK, London.

Francis, L.J., 1997, 'The psychology of gender differences in religion: A review of empirical research', Religion 27(1), 81-96. https://doi.org/10.1006/reli. 1996.0066

Francis, L.J., 2005, Faith and psychology: Personality, religion and the individual, Darton, Longman and Todd, London.

Francis, L.J., 2013, 'The psychological type profile of a church: A case study', Comprehensive Psychology 2(1), 6. https://doi.org/10.2466/01.09.CP.2.6

Francis, L.J., 2016, 'New directions in clergy psychological profiling. Connections with church growth?', Theology 119(2), 91-98. https://doi. org/10.1177/0040571X15615329

Francis, L.J., Clymo, J. \& Robbins, M., 2014, 'Fresh expressions: Reaching those psychological types conventional forms of church find it hard to reach?', Practical Theology 7(4), 252-267. https://doi.org/10.1179/1756073X14Z.00000000045

Francis, L.J., Craig, C.L. \& Hall, G., 2008, 'Psychological type and attitude toward Celtic Christianity among committed churchgoers in the United Kingdom: An empirical study', Journal of Contemporary Religion 23(2), 181-191. https://doi. org/10.1080/13537900802024543

Francis, L.J., Craig, C.L., Whinney, M., Tilley, D. \& Slater, P., 2007a, 'Psychological typology of Anglican clergy in England: Diversity, strengths, and weaknesses in ministry', International Journal of Practical Theology 11(2), 266-284. https://doi. org/10.1515/IJPT.2007.17 
Francis, L.J., Duncan, B., Craig, C.L. \& Luffman, G., 2004, 'Type patterns among Anglican congregations in England', Journal of Adult Theological Education 1(1), 66-77. https://doi.org/10.1558/jate.1.1.65.36058

Francis, L.J., Edwards, O. \& ap Siôn, T., 2020, 'Applying psychological type and psychological temperament theory to the congregations at cathedral caro services', Mental Health, Religion, and Culture. https://doi.org/10.1080/136746 76.2020.1764516

Francis, L.J., Jones, S.H. \& Hebden, K., 2019, 'Binding and loosing on earth: Evaluating the strategy for church disciplinary procedures proposed in Matthew 18: 15-18 through the lenses of thinking and feeling', HTS Theological Studies 75(3), article 5474, 1-10. https://doi.org/10.4102/hts.v75i3.5476

Francis, L.J. \& Lankshear, D.W., in press, The science of congregation studies: Looking for signs of growth, Palgrave Macmillan, New York, NY.

Francis, L.J., Laycock, P. \& Brewster, C., 2017, 'Exploring the factor structure of the Francis Psychological Type Scales (FPTS) among a sample of Anglican clergy in England', Mental Health, Religion and Culture 20(9), 930-941. https://doi.org/1 0.1080/13674676.2017.1375469

Francis, L.J. \& Penny, G., 2014, 'Gender differences in religion', in V. Saroglon (ed.), Religion, personality and social behaviour, pp. 191-209, Psychology Press, New York, NY

Francis, L.J. \& Richter, P., 2007, Gone for good? Church-leaving and returning in the 21st century, Epworth, Peterborough.

Francis, L.J. \& Robbins, M., 2012, 'Not fitting in and getting out. Psychological type and congregational satisfaction among Anglican churchgoers in England', Mental Health, Religion and Culture 15(10), 1023-1035. https://doi.org/10.1080/13674 Health, Religion and
676.2012 .676260

Francis, L.J., Robbins, M. \& Craig, C.L., 2011, 'The psychological type profile of Anglican churchgoers in England: Compatible or incompatible with their clergy?', International Journal of Practical Theology 15(2), 243-259. https://doi. org/10.1515/IJPT.2011.036

Francis, L.J., Robbins, M. \& Ryland, A., 2012, 'Called for leadership: Psychological type profile of leaders within the Newfrontiers network of churches in the United Kingdom', Journal of Psychology and Theology 40(3), 220-228. https://doi. org/10.1177/009164711204000305

Francis, L.J., Robbins, M., Williams, A. \& Williams, R., 2007b, 'All types are called, but some are more likely to respond: The psychological profile of rural Anglican churchgoers in Wales', Rural Theology 5(1), 23-30. https://doi.org/10.1179/ rut_2007_5_1_003

Francis, L.J. \& Ross, C.F., 2018, 'Psychologically-informed engagement with the Matthean pericopes on Pilate and Judas through Jungian lenses: The SIFT approach', HTS Theological Studies 74(1), article 5179, 1-12. https://doi. org/10.4102/hts.v74i1.5179

Francis, L.J. \& Village, A., 2008, Preaching with all our souls, Continuum, London.

Francis, L.J. \& Village, A., 2015, 'Go and observe the sower: Seeing empirical theology at work', Journal of Empirical Theology 28(2), 155-183. https://doi. org/10.1163/15709256-12341325

Francis, L.J., Wright, H. \& Robbins, M., 2016, 'Temperament theory and congregation studies: Different types for different services?', Practical Theology 9(1), 29-45. https://doi.org/10.1080/1756073X.2016.1149679

Gaze, S., 2006, Mission-shaped and rural: Growing churches in the countryside, Church House Publishing, London.

Gerhardt, R., 1983, 'Liberal religion and personality type', Research in Psychological Type 6(1), 47-53.

Goodhew, D., Roberts, A. \& Volland, M., 2012, Fresh: An introduction to fresh expressions of church and pioneer ministry, SCM Press, London.

Hope, S., 2006, Mission-shaped spirituality: The transforming power of mission, Church House Publishing, London.

Hull, J.M., 2006, Mission-shaped church: A theological response, SCM, London.

Jung, C.G., 1971, Psychological types: The collected works, vol. 6, Routledge and Kegan Paul, London.

Keirsey, D. \& Bates, M., 1978, Please understand me, Prometheus Nemesis, Del Mar, CA.

Kendall, E., 1998, Myers-Briggs type indicator: Step 1 manual supplement, Consulting Psychologists Press, Palo Alto, CA.

Kennerley, P., 2015, Dean Dwelly of Liverpool: Liturgical genius, Carnegie Publishing, Lancaster.

Lewis, C.A., Varvatsoulias, G. \& Williams, E., 2012, 'Psychological type profile of practising Greek Orthodox churchgoers in London', Mental, Health, Religion and Culture 15(10), 979-986. https://doi.org/10.1080/13674676.2012.720753

Lings, G., 2016, The day of small things: An analysis of fresh expressions of church in 21 dioceses of the Church of England, Church Army, Sheffield. https://doi. org/10.4324/9781315260297-13

McCaulley, M.H., 1985, 'The selection ratio type table: A research strategy for comparing type distributions', Journal of Psychological Type 10(1), 46-56.
Millbank, J., 2008, 'Stale expressions: The management-shaped Church', Studies in Christian Ethics 21(1), 117-128. https://doi.org/10.1177/0953946808089730

Moore, L., 2006, Messy Church: Fresh ideas for building a Christ-centred community, Bible Reading Fellowship, Abingdon.

Moynagh, M., 2012, Church for every context: An introduction to theology and practice, SCM, London.

Myers, I.B. \& McCaulley, M.H., 1985, Manual: A guide to the development and use of the Myers-Briggs type indicator, Consulting Psychologists Press, Palo Alto, CA.

Nelstrop, L. \& Percy, M., 2008, Evaluating fresh expressions: Explorations in emerging Church, Canterbury Press, Norwich.

Paul, I. (ed.), 2017, Being messy, being Church, Bible Reading Fellowship, Abingdon.

Percy, M., 2010, Shaping the church: The promise of implicit theology, Ashgate, Farnham.

Rehak, M.C., 1998, 'Identifying the congregation's corporate personality', Journal of Psychological Type 44(1), 39-44.

Richter, P. \& Francis, L.J., 1998, Gone but not forgotten: Church leaving and returning, Darton, Longman and Todd, London.

Robbins, M. \& Francis, L.J., 2011, 'All are called, but some psychological types are more likely to respond: Profiling churchgoers in Australia', Research in the Social Scientific Study of Religion 22(1), 213-229. https://doi.org/10.1163/ ej.9789004207271.i-360.44

Robbins, M. \& Francis, L.J., 2012, 'The psychological type profile of Australian Catholic congregations: Psychological theory and congregational studies', in A.W. Ata (ed.), Catholics and Catholicism in contemporary Australia: Challenges and achievements, pp. 262-281, David Lovell Publishing, Melbourne.

Robbins, M., Francis, L.J. \& Powell, R., 2012, 'Congregational bonding social capital and psychological type: An empirical enquiry among Australian churchgoers', Mental Health, Religion and Culture 15(10), 1009-1022. https://doi.org/10.108 $0 / 13674676.2012 .676264$

Ross, C.F.J., 1993, 'Type patterns among active members of the Anglican Church: Comparisons with Catholics, Evangelicals and clergy', Journal of Psychological Type 26(1), 28-35.

Ross, C.F.J., 1995, 'Type patterns among Catholics: Four Anglophone congregations compared with Protestants, Francophone Catholics and priests', Journal of Psychological Type 33(1), 33-41.

Ross, C.F.J. \& Francis, L.J., 2020, Personality, religion, and leadership: The spiritual dimensions of psychological type theory, Lexington Books, New York, NY.

Smith, A., 2008, God-shaped mission: Theological and practical perspectives from the rural Church, Canterbury Press, Norwich.

Smith, G., 2015, 'Psychological type and the training relationship: An empirical study among curates and training incumbents', Mental Health, Religion and Culture 18(7), 556-565. https://doi.org/10.1080/13674676.2014.963998

Smith, G. \& Francis, L.J., 2015, 'Experiencing and reflecting on thinking and feeling in pastoral care: Deploying psychological type theory in continuing ministerial formation', Journal of Adult Theological Education 12(1), 69-78. https://doi.org/1 formation', Journal of Adult Theological
$0.1179 / 1740714115 Z .00000000037$

Sudworth, T., Cray, G. \& Russell, C., 2007, Mission-shaped youth: Rethinking young people and the Church, Church House Publishing, London.

Village, A., 2015, 'Who goes there? Attendance at fresh expressions of Church in relation to psychological type preference among readers of the Church Times', Practical Theology 8(2), 112-129. https://doi.org/10.1179/175607481 Times', Practical

Village, A., Baker, S. \& Howat, S., 2012, 'Psychological type profiles of churchgoers in England', Mental Health, Religion and Culture 15(10), 969-978. https://doi.org/

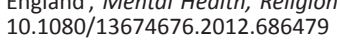

Voas, D. \& Bruce, S., 2019, 'Religious identity, behaviour and belief over two decades', in J. Curtis, E. Clergy, J. Perry, M. Phillips \& N. Rahim (eds.), British social attitudes, vol. 36, pp. 17-44, The National Centre for Social Research, London.

Voas, D. \& Watt, L., 2014, Numerical change in church attendance: National, local and individual factors (The Church Growth Research Programme: Report on strands 1 and 2), Church of England, London.

Walker, D.S., 2012, 'O come all ye thinking types: The wider appeal of the cathedral carol service', Mental Health, Religion and Culture 15(10), 987-995. https://doi.or $\mathrm{g} / 10.1080 / 13674676.2012 .707436$

Walker, D.S., 2017, God's belongers: How people engage with God today and how the church can help, The Bible Reading Fellowship, Abingdon.

Walker, J., 2014, Testing fresh expressions: Identity and transformation, Ashgate, Farnham.

Withers, M., 2006, Mission-shaped children: Moving towards a child-centred church, Church House Publishing, London. 